\title{
Biomechanics and clinical outcome after posterior stabilization of mid-thoracic vertebral body fractures: a systematic literature review
}

\author{
Ulrich J. Spiegl ${ }^{1}$ (1) - Georg Osterhoff ${ }^{1} \cdot$ Philipp Bula $^{2} \cdot$ Frank Hartmann $^{3} \cdot$ Max J. Scheyerer $^{4} \cdot$ Klaus J. Schnake $^{5}$. \\ Bernhard W. Ullrich ${ }^{6}$
}

Received: 18 September 2020 / Accepted: 16 November 2020 / Published online: 2 December 2020

(c) The Author(s) 2020

\begin{abstract}
Purpose The aim of this review is to systematically screen the literature for clinical and biomechanical studies dealing with posterior stabilization of acute traumatic mid-thoracic vertebral fractures in patients with normal bone quality.

Methods This review is based on articles retrieved by a systematic search in the PubMed and Web of Science database for publications up to December 2018 dealing with the posterior stabilization of fractures of the mid-thoracic spine.

Results Altogether, 1012 articles were retrieved from the literature search. A total of 960 articles were excluded. A total of 16 articles were dealing with the timing of surgery in polytraumatized patients, patients suffering of neurologic deficits after midthoracic fractures, and the impact of concomitant thoracic injuries and were excluded. Thus, 36 remaining original articles were included in this systematic review depicting the topics biomechanics, screw insertion, and outcome after posterior stabilization. The overall level of evidence of the vast majority of studies is low.

Conclusion High quality studies are lacking. Long-segmental stabilization is indicated in unstable midthoracic fractures with concomitant sternal fractures. Generally, long-segmental constructs seem to be the safer treatment strategy considering the relative high penetration rate of pedicle screws in this region. Thereby, navigated insertion techniques and intraoperative 3D-imaging help to improve pedicle screw placement accuracy.
\end{abstract}

Keywords Thoracic spine fractures $\cdot$ Posterior stabilization $\cdot$ Clinical outcome $\cdot$ Pedicle screw placement $\cdot$ Additional thoracic injuries

Ulrich J. Spiegl

uli.spiegl@gmx.de

1 Department of Orthopaedics, Trauma Surgery and Plastic Surgery, University of Leipzig, Liebigstr. 20, 04103 Leipzig, Germany

2 Department of Orthopaedics and Trauma Surgery, Klinikum Gütersloh, Gütersloh, Germany

3 Center for Trauma and Orthopedic Surgery, Gemeinschaftsklinikum Mittelrhein, Ev. Stift, Koblenz, Germany

4 Department of Orthopedics and Trauma Surgery, University Hospital of Cologne, Cologne, Germany

5 Center for Spinal and Scoliosis Surgery, Malteser Waldkrankenhaus St. Marien, Erlangen, Germany

6 Department of Trauma Surgery and Reconstructive Surgery, BG Klinikum Bergmannstrost, Halle, Germany

\section{Introduction}

The majority of traumatic vertebral fractures occur at the thoracolumbar junction and less commonly at the midthoracic or mid-lumbar spine [32]. In accordance, a high number of articles are dealing with thoracolumbar fractures focusing on the thoracolumbar junction. Nonetheless, the anatomy and biomechanics of the mid-thoracic spine differ from the thoracolumbar junction. First of all, the vertebral bodies including the pedicles are smaller at the thoracic spine, the orientation of the facet joints is different allowing rotational motion [44]. Next, the thoracic cage, defined as the fourth column by several authors, stabilizes the thoracic spine and leads to a higher stiffness [39]. Last but not least, the sagittal alignment of the thoracic spine consisting of a kyphosis differs tremendously from the thoracolumbar junction and the lordotic lumbar spine [33].

Based on these differences, the thoracic spine needs to be analyzed separately. According to literature, posterior 
stabilization is the most common used treatment strategy in unstable mid-thoracic fractures [37].

The aim of this review is to systematically review the literature for clinical and biomechanical studies dealing with posterior stabilization of acute traumatic mid-thoracic vertebral fractures. From this, the current state of evidence considering all aspects of the posterior stabilization shall be described. Based on these results, prospective studies could be created to increase the evidence in this field.

\section{Methods}

The literature search included unstable recent vertebral fractures ( $<4$ weeks) of the mid-thoracic spine (Th 2-Th 10) of adults treated by posterior stabilization with adequate trauma history. Children and adolescents (age < 18) and elderly (age $>65$ ) with likely concomitant osteopenia/osteoporosis were not within the scope of this review and need to be analyzed separately. Furthermore, patients with fractures after non-adequate trauma (trivial falls from tripping) were not included in this review.

A systematic search of the literature was performed by two of the authors (UJS, BWU), including all articles until 12/26/2018. In each case, the two databases PubMed and Web of Science Core Collection were considered and searched. Excluded were articles dealing with osteoporotic or pathologic vertebral body fractures, cervical and/or lumbar vertebral body fractures, and exclusively non-operative therapy strategies. Furthermore studies dealing with the timing of surgery in polytraumatized patients, patients suffering of neurologic deficits after midthoracic fractures, and the impact of concomitant thoracic injuries and were excluded. Additionally, case reports, reviews, and animals studies were excluded. Since data collection had already been completed at the time of PROSPERO registration, this review could not be registered with PROSPERO. Using the PICO scheme [11], the following review questions were defined:

- What is the recommended insertion technique of pedicle screws at the mid-thoracic spine?

- Short or long segmental stabilization-what should be preferred

- What is the expected outcome of fractures of the midthoracic spine treated by posterior stabilization?

The following search terms were used: "thoracic vertebral body fractures" OR "thoracic vertebral spine fractures" NOT “Osteoporosis" NOT "case report” NOT "tumor” NOT "lumbar spine".

Subsequently, all relevant original articles were analyzed based on their levels of evidence and their appropriate conclusions. Here, the following topic areas were defined:
- Biomechanics

- Screw insertion

- Outcome after posterior stabilization

\section{Results}

Altogether, 1012 abstracts were retrieved from the literature search (Fig. 1). Of these, articles were excluded based on abstract or title. Most of the excluded studies were overlaps between both databases, animals studies, no original articles or were articles investigated other pathologies or included cervical or lumbar factures, or exclusively evaluated nonoperative treatment or anterior approaches. Altogether, 78 articles were analyzed completely. Of these articles 26 were additionally excluded, not focusing specifically on the thoracic spine, including geriatric patients or insufficiently describing the method of posterior stabilization. A total of 16 articles analyzed the timing of surgery in polytraumatized patients, reported of patients suffering of neurologic deficits after midthoracic fractures, and evaluated the impact of concomitant thoracic injuries and were excluded. Altogether, 976 articles were excluded (Fig. 1). All 36 remaining original articles, which covered the period from 1971 to 2018 are summarized in Tables 1, 2 and 3. Levels of evidence were defined as described by Bassler and Antes [1].

\section{Biomechanics}

A total of five studies dealt with mainly biomechanical aspects of posterior stabilization of thoracic fractures (Table 1). Generally, the thoracic spine is biomechanically stiffer than the other regions of the spine, because of two anatomical characteristics: the first one is the articulation of

\section{Flow Chart of the Systematic Literature Review}

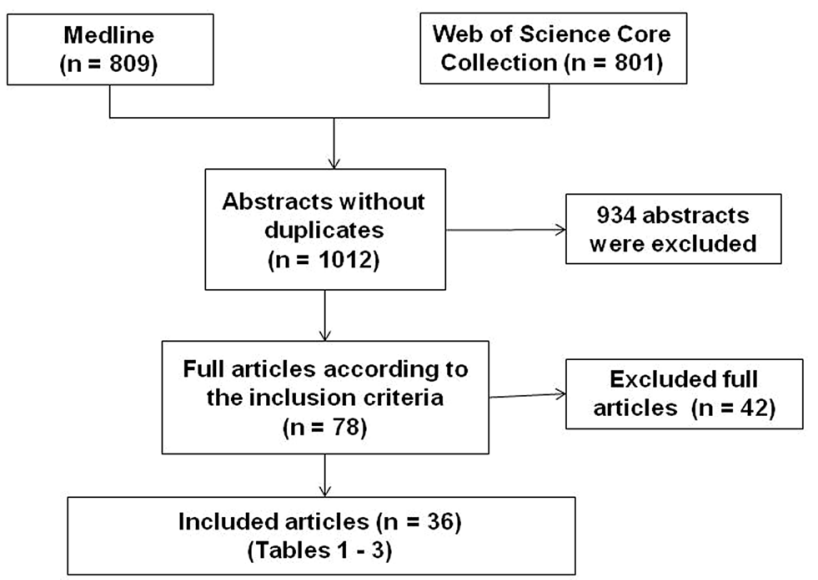

Fig. 1 Flow chart of the systematic literature review 
Table 1 Biomechanical studies

\begin{tabular}{|c|c|c|}
\hline Study & Purpose & Key message \\
\hline Watkin et al. [43] (2005) & Amount of stability provided by the rib cage & $\begin{array}{l}\text { The intact rib cage provides high stability in all motion } \\
\text { directions } \\
\text { Sternal fractures decrease stability particularly in } \\
\text { extension-flexion motion }\end{array}$ \\
\hline Perry et al. [30] (2014) & $\begin{array}{l}\text { Long segment versus short segment instrumentation in } \\
\text { thoracic burst fracture }\end{array}$ & $\begin{array}{l}\text { Long segment instrumentation superior during flexion- } \\
\text { extension } \\
\text { During lateral bending and axial rotation short and long } \\
\text { instrumentations are comparable }\end{array}$ \\
\hline Lazaro et al. [24] (2011) & $\begin{array}{l}\text { Long segment instrumentation versus short instrumenta- } \\
\text { tion with cross-links and/or index screws }\end{array}$ & $\begin{array}{l}\text { Index screws increase stability about } 25 \% \\
\text { Cross-links only stabilize during axial rotation }\end{array}$ \\
\hline Hongo et al. [18] (2009) & $\begin{array}{l}\text { Metal clamps combined with polyester belts versus sub- } \\
\text { laminar wiring versus hooks versus pedicle screws }\end{array}$ & Pedicle screw fixation is superior \\
\hline Little et al. [26] (2010) & Costotransverse process screws versus pedicle screws & Pedicle screw fixation is superior \\
\hline
\end{tabular}

the head of the ribs with the articular facets of the adjacent vertebral bodies in combination with the radiate ligaments, which attach to the head of the ribs and both adjacent vertebral bodies, and the costotransverse ligaments. The second is the structure of the thoracic cage itself, which increases the resistance to all directions of motion [44]. Watkins et al. [43] evaluated the amount of stability provided by the rib cage and the sternum. In their study, the intact rib cage provided $40 \%$ of the stability of the thoracic spine in flexion-extension, $35 \%$ in lateral bending and $31 \%$ in axial rotation. A sternal fracture decreased the stability of the thoracic spine significantly by $42 \%$ in flexion-extension, $22 \%$ in lateral bending and $15 \%$ in axial rotation. Berg et al. [3] observed two clinical cases of combined sternal and thoracic spine fractures, which developed significant kyphotic deformities after nonoperative treatment and postulated the sternal-rib complex as the fourth column of the spine based on the three column theory of the spine by Denis. In general, the structural instability of thoracic fractures is treated with posterior instrumentation 2 levels above and below the fracture site, but in case of intact rib cage a short segment fixation with 1 level above and below the fractured vertebra could be an alternative. Therefore, Perry et al. [30] created a burst fracture at T9 in eight human thoracic spines (C7-L1) with intact rib cages and tested a long segment instrumentation (3 above, 2 below), a short segment instrumentation (1 above/1 below) with and without vertebral augmentation and vertebral augmentation without instrumentation. In their study, the long segment instrumentation showed a significant reduction of ROM during flexion-extension $(-90 \%)$, whereas the other instrumentations only tended to reduce motion. However, Perry et al. [30] suggested that in case of intact rib cages short segment instrumentation might adequately stabilize the spine. A common strategy to increase stability of short segment fixation is the addition of cross-links or screws at fracture site (index screws). Lazaro et al. [24] evaluated seven human thoracic spine segments after creating a wedge fracture in five conditions: long segment fixation ( 2 above/ 2 below) with cross-link, short segment fixation ( 1 above/1 below), short segment fixation with cross links, short segment fixation with index screws and short segment fixation with index screws and cross-link. The long segment fixation was significantly stiffer than short segment fixation, but adding index screws to the short segment construct significantly improved stability by $25 \%$. Adding the cross-link increased stability only during axial rotation. Alternative fixation devices or techniques for the thoracic spine have been described, but pedicle screw systems still provide superior biomechanical properties $[18,26]$. All relevant articles are summarized in Table 1.

\section{Placement of thoracic pedicle screws}

\section{Transpedicular pedicle screws}

Seventeen studies evaluated screw positioning, screw implantation and intra-operative control of screw placement (Table 2). The Placement of pedicle screws in the straight ahead technique promoted by Roy-Camille et al. [34] is associated with a penetrating rate of $41 \%$ [40]. Generally, structures at risk were the intercostal vessel (T4-5), esophagus (T5-9), diaphragm, azygos vein (T5-11), inferior vena cava (T11-12) on the right side as well as aorta (T5-12) and esophagus (T4-9) on the left side.

Dwahan et al. [9] analyzed the effective pedicle diameter and the mean insertion angle comparing three types of insertion techniques (straight ahead, straight forward with angulation in the axial plane, and anatomic with angulation in the axial and sagittal planes) and found the largest effective diameter using the anatomic way.

Additionally, the funnel technique, opening the insertion point to visualize the medial cortex of the lamina, was analyzed in a cadaver study [6]. The authors had a low perforating rate of $10 \%$ grade 1 and $0.4 \%$ grade 2 . 
Table 2 Studies dealing with pedicle screw placement

\begin{tabular}{|c|c|c|c|c|c|}
\hline $\begin{array}{l}\text { Study } \\
\text { (year) }\end{array}$ & Purpose & Study design & No of screws & Main message & Ev-L \\
\hline Vaccari et al. [40] (1995) & $\begin{array}{l}\text { Pedicle screw insertion in } \\
\text { Roy-Camille technique }\end{array}$ & Cadaver study & 90 & $\begin{array}{l}\text { Screw penetration rate of } \\
41 \%\end{array}$ & n.a \\
\hline Kothe et al. [22] (2001) & $\begin{array}{l}\text { Navigated parapedicular } \\
\text { insertion technique }\end{array}$ & Cadaver study & 54 & Safe and reliable technique & n.a \\
\hline Reidy et al. [31] (2001) & $\begin{array}{l}\text { Is intraoperative EMG-moni- } \\
\text { toring necessary }\end{array}$ & Prospective cohort study & 95 & $\begin{array}{l}\text { No improvement in accuracy } \\
\text { could be observed }\end{array}$ & II \\
\hline Husted et al. [21] (2003) & Parapedicular approach & Cadaver study & 24 & $\begin{array}{l}\text { No spinal canal penetration } \\
\text { No pleural or foraminal } \\
\text { penetration }\end{array}$ & n.a \\
\hline Schnake et al. [35] (2004) & Navigated screw insertion & Prospective cohort study & 324 & $\begin{array}{l}\text { Significant reduction in all } \\
\text { screw penetrations } \\
\text { Significant reduction in rel- } \\
\text { evant screw penetration }\end{array}$ & II \\
\hline $\begin{array}{l}\text { Mac-Thiong et al. [27] } \\
\text { (2003) }\end{array}$ & $\begin{array}{l}\text { Evaluation of special drill } \\
\text { guide for pedicle screw } \\
\text { accuracy }\end{array}$ & Cadaver study & 66 & $\begin{array}{l}\text { No screw penetration of } \\
\text { more than } 2 \mathrm{~mm} \text { could be } \\
\text { seen }\end{array}$ & IV \\
\hline Bransford et al. [4] (2006) & $\begin{array}{l}\text { Accuracy of free-hand pedi- } \\
\text { cle screw placement under } \\
\text { fluoroscopic control }\end{array}$ & Retrospective case series & 1533 & $\begin{array}{l}\text { No major complication was } \\
\text { observed } \\
1.2 \% \text { of prophylactic revision } \\
\text { surg. due to screw malposi- } \\
\text { tion }\end{array}$ & IV \\
\hline Dhawan et al. [9] (2008) & $\begin{array}{l}\text { Comparison of the pedicle } \\
\text { screw insertion direction }\end{array}$ & Cadaver study & 966 & $\begin{array}{l}\text { The anatomic position leads } \\
\text { to a } 20 \% \text { larger effective } \\
\text { pedicle diameter }\end{array}$ & n.a \\
\hline Chan et al. [6] (2010) & $\begin{array}{l}\text { Evaluating the funnel tech- } \\
\text { nique }\end{array}$ & Cadaver study & 240 & $\begin{array}{l}\text { No medial pedicle penetra- } \\
\text { tion by direct visualization } \\
\text { via wide laminectomy }\end{array}$ & n.a \\
\hline Wu et al. [43] (2010) & $\begin{array}{c}\text { Free-hand versus navigated } \\
\text { pedicle screw placement }\end{array}$ & Prospective randomized trial & 176 & $\begin{array}{l}\text { Significant less pedicle screw } \\
\text { penetrations with naviga- } \\
\text { tion } \\
\text { Significant reduced radiation } \\
\text { time with navigation } \\
\text { Faster pedicle screw place- } \\
\text { ment with navigation }\end{array}$ & II \\
\hline Beck et al. [2] (2012) & $\begin{array}{l}\text { Benefit of intraoperative } \\
\text { 3D-imaging for pedicle } \\
\text { screw accuracy }\end{array}$ & Prospective case series & 240 & $\begin{array}{l}3.8 \% \text { intraoperative pedicle } \\
\text { screw revision } \\
2.5 \% \text { of postoperative pedicle } \\
\text { screw penetration, all grade } \\
\text { I }(<2 \mathrm{~mm})\end{array}$ & III \\
\hline Lehmann et al. [25] (2014) & $\begin{array}{l}\text { Identification of the ideal } \\
\text { starting point of pedicle } \\
\text { screw insertion }\end{array}$ & Cadaver study & 229 & $\begin{array}{l}2-3 \mathrm{~mm} \text { lateral to the } \\
\text { midline of the superior } \\
\text { articular facet }\end{array}$ & n.a \\
\hline Cho et al. [7] (2015) & $\begin{array}{l}\text { Feasibility of translaminar } \\
\text { screws }\end{array}$ & Cadaver study & 294 & $\begin{array}{l}\text { Safe technique } \\
\text { Small number of moderate } \\
\text { penetrations }\end{array}$ & n.a \\
\hline Gonzalvo et al. [16] (2015) & $\begin{array}{l}\text { Pedicle penetration rate in } \\
\text { dependeny of the pedicle } \\
\text { diameter }\end{array}$ & Retrospective case series & 218 & $\begin{array}{l}\text { Penetration rate of } 33 \% \text { : } \\
\text { pedicles diameter }<5 \mathrm{~mm} \\
\text { Penetration rate of } 11 \%: \\
\text { Pedicle diameter } 5-7 \mathrm{~mm} \\
\text { No penetrations if pedicle } \\
\text { diameter }>7 \mathrm{~mm}\end{array}$ & IV \\
\hline $\begin{array}{l}\text { Hu et al. [19] } \\
(2015)\end{array}$ & $\begin{array}{l}\text { Anatomic feasibility of trans- } \\
\text { laminar screw placement }\end{array}$ & Cadaver study & 6 & $\begin{array}{l}\text { Translaminar screws are } \\
\text { not limited by anatomy in } \\
\text { Asian patients }\end{array}$ & n.a \\
\hline
\end{tabular}


Table 2 (continued)

\begin{tabular}{|c|c|c|c|c|c|}
\hline $\begin{array}{l}\text { Study } \\
\text { (year) }\end{array}$ & Purpose & Study design & No of screws & Main message & Ev-L \\
\hline $\begin{array}{l}\text { Kwan et al. [23] } \\
\text { (2015) }\end{array}$ & $\begin{array}{l}\text { Comparison of pedicle screw } \\
\text { accuracy between percuta- } \\
\text { neous and open placement }\end{array}$ & Cadaver study & 288 & $\begin{array}{l}\text { Percutaneous technique has a } \\
\text { similar accuracy compared } \\
\text { to the open placement } \\
\text { Penetration rate: } 11 \% \text { open } \\
\text { versus } 8 \% \text { percutaneous }\end{array}$ & n.a \\
\hline $\begin{array}{l}\text { Fischer et al. [12] } \\
\text { (2016) }\end{array}$ & $\begin{array}{l}\text { Gguide wire-based pedicle } \\
\text { screw insertion under CT- } \\
\text { imaging }\end{array}$ & Retrospective case series & 286 & $\begin{array}{l}\text { Very high accuracy and low } \\
\text { complication rate using this } \\
\text { technique }\end{array}$ & IV \\
\hline
\end{tabular}

Another way to improve the accuracy could be the use of a special drill guide as tool for thoracic pedicle screw placement [27]. Only 5 of 66 screws had a perforation, all less than $2 \mathrm{~mm}$.

Lehmann et al. [25] analyzed 229 pedicles in an anatomic study. The authors found an ideal starting point 2-3 $\mathrm{mm}$ lateral to the midline of the superior articular facet (line between the lateral and the middle third of the superior facet). The cephalocaudal point is more level depending. T7-9 at the cranial border of the transverse process, T6 and T10 between the cranial border and proximal one-third of transverse process, T4-5 and T11 proximal one third of transverse process and T1-3 and T12 bisected transverse process.

In a clinical setting, Bransfold et al. [4] reported of $1.2 \%$ revision surgery rate due to screw misplacement in 245 patients treated because of thoracic fractures in an open technique under fluoroscopic control. Thereby, there seems to be a correlation between pedicle diameter and penetration rate with a $33 \%$ misplacement rate in pedicle diameters of less than $5 \mathrm{~mm}$ to $11 \%$ in diameters between 5 and $7 \mathrm{~mm}$ and no misplacement in diameters above $7 \mathrm{~mm}$ [16]. Altogether, there seems to be no difference in accuracy of screw placement in thoracic spine between the open and percutaneous technique [23].

Two studies investigated the benefit of navigation for pedicle screw placement in the thoracic spine [35, 45]. Both studies found significant higher accuracy in the navigated pedicle screw placement technique. Alternatively, intraoperative 3D-Imaging using a cone-beam device can be used to improve accuracy [2]. A total of $3.8 \%$ of the pedicle screws were re-implanted due to the findings in the 3D-Scan. No penetration of more than $2 \mathrm{~mm}$ was seen postoperatively. Additionally, Fischer et al. [12] used preoperative CT-guided transpedicular guide wires and reported a high accuracy and a low complication rate.

In contrast, intraoperative electromyographic monitoring could not improve the accuracy of transpedicular screw placement in thoracic spine [31].

\section{Parapedicular pedicle screws}

The insertion of pedicle screws parapedicularly is an alternative to the transpedicular screws placement [10]. The accuracy of this technique under computer-assisted navigation was good and reliable [22].

Husted et al. [21] performed a cadaver study for the parapedicular approach. In this technique, the screws were inserted cephalad to the tip of the transverse process and advanced between the transverse process and the rib. The direction of insertion was caudad in an oblique direction following the course of the rib medially to its articulation with the vertebral body under fluoroscopic control. All screws had an extraspinal position and were positioned in the pedicle rib unit.

\section{Translaminar screws}

Alternatively, translaminar screw fixation has been evaluated, which can be inserted with high accuracy under clinically control [7].

$\mathrm{Hu}$ et al. [19] analyzed the laminar of the high thoracic spine (Th 1-3) in an Asian population. The authors found larger lamina in males than females but sufficient corridors in all cases.

\section{Outcome after posterior stabilization}

There were 14 clinical studies evaluating the outcome in patients with unstable thoracic fractures (Table 3). Most studies on non-operative treatment of unstable fractures are historical. They report treatment algorithms that include bedrest for 2-6 weeks [5, 17, 48]. Hospitalisation times with non-operative treatment range from 3 weeks to 3 months $[5,17]$ and can be reduced to between less than 2 weeks and 3 weeks by operative treatment in patients with isolated thoracic vertebral fractures [13, 14].

After surgical treatment of thoracic vertebral fractures by posterior stabilization in general, non-surgery-related 


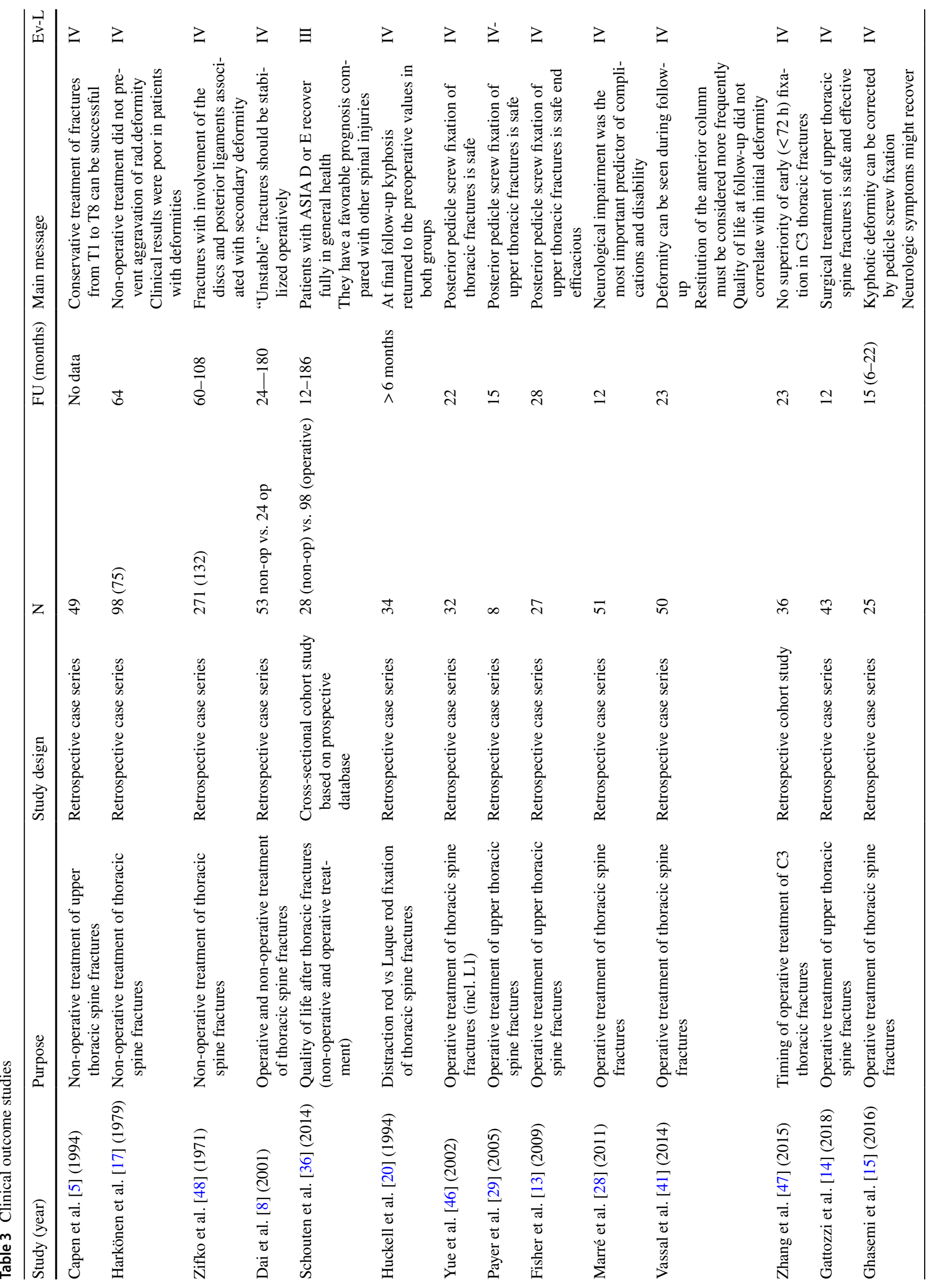


complications occur in 49\%-60\%, especially in patients with complete or incomplete paraplegia [28, 46]. Deep venous thrombosis is observed in 4\%-9\% [13, 36]-compared to $24.5 \%$ in conservatively treated patients [5]. This results in an in-hospital mortality rate of $6 \%-8 \%[46,47]$. Neurologic worsening during follow-up can be reduced from around $2 \%$ $[5,48]$ with non-operative treatment to less than $1 \%$ with posterior stabilization $[28,29,45,46]$. The only complication directly linked to the non-operative treatment is brace-related skin complications in $16 \%$ [5]. For surgical posterior stabilization, the need for revision surgery is reported in 0 to $22 \%$ $[13,15,29,36,41,46]$. Some authors differentiate between early revision surgery in 4\%-19\% and late revision surgery in $16 \%-22 \%$ - with late revisions being mainly those for pain and low-grade-infection [13, 14, 28]. One study identified lamina hooks as source of potential neurological complications requiring revision surgery [41].

Radiological secondary deformity was seen in $94 \%$ with non-operative-management, particularly in fractures with associated injuries to the adjacent disc and/or posterior ligaments $[17,48]$. With posterior stabilization, a loss of reduction of $1^{\circ}$ to $4^{\circ}$ was observed after 1 year and of $2^{\circ}$ to $4^{\circ}$ after 2 years and more $[13,14,29,41]$. The only study reporting data on bone healing stated a fusion rate of $95 \%$ at 12 months on conventional radiographs [14].

Pain at follow-up after non-operative treatment was reported by $21 \%$ to $48 \%$ of the patients at 5 years and longer, while this was the case in $35 \%$ with a mean of VAS 3 at 15 months after operative treatment with posterior stabilization $[5,8,17$, 48]. Harkönen et al. [17] reported that $13 \%$ of the patients had "poor" mobility at 5 years with non-operative treatment, while Yue et al. [46] reported "very good to excellent levels of satisfaction with regards to pain, mobility, posture, and activity" 22 months after posterior stabilization.

Only few studies report patient-reported outcomes for operatively treated patients with values for the SF 36-PCS of 36-40 and the SF 36-MCS of 43-56 [36, 41]. No difference in functional outcome was seen between short and long segmental construct. Generally, return to work was less likely in patients with concomitant spinal cord injuries (25\% of ASIA $\mathrm{A} / \mathrm{B} / \mathrm{C}$ and $88 \%$ of ASIA D/E) [36]. One year after posterior stabilization of a thoracic vertbral fracture, $7.8 \%$ received compensation payments for chronic back pain [28].

There is also some evidence that percutaneous posterior stabilization of thoracic spine fractures is associated with a reduced inflammatory response, less bleeding, shorter hospitalisation time and earlier return to activities of daily living $[20,42]$.

\section{Discussion}

The majority of articles that were selected had a low level of evidence (level IV). Thus, no strength of evidence and statistical precision in the evaluation of the outcomes was performed. In contrast, a narrative presentation of the results was chosen.

Based on this, the most important findings of this study are the low evidence on posterior stabilization of midthoracic vertebral body fractures particularly dealing with clinical outcomes can be observed. Besides, the tremendous effect of sternal integrity on spinal stability has been shown. Furthermore, the penetration rates of pedicle screws varies between the studies ranging up to $40 \%$ based on the rather small pedicle diameters at the upper thoracic spine. Thereby, the accuracy of pedicle screw placement could be improved by navigated pedicle screw insertion as well as intraoperative 3D-Imaging and the insertion should be done anatomically.

Most authors perform long-segmental posterior instrumentation in patients with mid-thoracic vertebral fractures $[4,29,38,41]$. This seems to be necessary particularly in patients with concomitant sternal fractures [30]. Based on the findings on the association of pedicle diameters and penetration rates, navigated techniques or intraoperative 3D-Imaging should be particularly used in pedicle diameters of less than $5 \mathrm{~mm}[2,16,35,45]$. In small pedicles, translaminar screws at the upper thoracic spine or parapedicular screws might be a viable alternative [7, 22]. Interestingly, percutaneous techniques were not associated with higher penetration rates. Therefore, percutaneous stabilization is a very good solution in long-segmental stabilizations and polytraumatized patients based on their reduced approach-related morbidity and significantly reduced blood loss [23].

Under consideration of these results, the authors generally recommend long-segmental stabilization of unstable midthoracic fractures in patients with concomitant fractures of the rib cage, particularly sternal fractures. On the other side, comparable biomechanical construct stabilities could be seen in unstable midthoracic fractures with intact rib cages between short-segmental stabilization with index screw and cross link and long-segmental stabilization. However, it has to be kept in mind that biomechanical tests are traditionally performed under ideal conditions, including optimal pedicle screw positioning. In contrast, it has been shown that pedicle screw placement was insufficient in a relevant number of patients with small pedicle including a penetration rate of $33 \%$ in pedicle diameters of less than $5 \mathrm{~mm}$ [16]. This can affect the screw hold considerably leading to impaired construct stability in patients treated with short-segment stabilization. Based on the 
limited pedicle screw diameters at the midthoracic spine, short-segmental stabilization has to be discussed critically in this region particularly as there are no signs of any functional benefit of short-segmental stabilization [36, 38]. In the authors' view short-segment stabilization is only a viable option in patients with large pedicle diameters, or in cases where navigation or intraoperative 3D-scans are used. In these cases, correct pedicle screw placement can be expected. Based on the biomechanical data shortsegment constructs should include index screws. Additionally, cross links improve the construct stability and should be added particularly when an open approach has been used. Furthermore, pedicle screws with a diameter as large as possible and a sufficient length should be used to increase construct stability. In the authors' experience, no pedicle screws with diameters of less than $5 \mathrm{~mm}$ should be inserted. Thereby, the authors recommend parapedicular screw placement in those patients with too small pedicle diameters.

Unfortunately, the evidence level of the clinical follow-up studies is low. Altogether, the results of posterior stabilization of unstable thoracic fractures are superior compared to non-operative treatment, with a lower rate of neurologic deterioration, higher return to work rates and lower limitations [28, 29, 46, 47]. However, the complication rate after both, operative and non-operative treatment is high $[26,41$, 47].

This study has several limitations. First of all, articles might have been missed by the used search items. Besides, the level of evidence in the majority of studies is low, leading to a limited conclusion that can be drawn out of it. Last but not least, the high number of studies with low evidence level was the reason to present the results in a narrative manner without any statistical evaluation of the strength of evidence and the precision of outcome parameters.

Altogether, further studies are necessary to define patients who benefit from surgery as well as which surgical strategies might lead to superior mid- and long-term results.

\section{Conclusions}

The evidence of the available literature is low. Prospective randomized studies are lacking. However, long-segmental stabilization is indicated in unstable midthoracic fractures with concomitant sternal fractures. Generally, long-segmental constructs seem to be the safer treatment strategy considering the relative high penetration rate of pedicle screws in this region. In the case of short-segmental stabilization, the use of index screw can be recommended. Additionally, pedicle screws with a diameter as large as possible should be used. Thereby, navigated insertion techniques and intraoperative 3D-imaging help to improve pedicle screw placement accuracy.

Funding Open Access funding enabled and organized by Projekt DEAL.

\section{Compliance with ethical standards}

Conflict of interest Georg Osterhoff is consultant for Medacta. No further conflict of interests exists.

Open Access This article is licensed under a Creative Commons Attribution 4.0 International License, which permits use, sharing, adaptation, distribution and reproduction in any medium or format, as long as you give appropriate credit to the original author(s) and the source, provide a link to the Creative Commons licence, and indicate if changes were made. The images or other third party material in this article are included in the article's Creative Commons licence, unless indicated otherwise in a credit line to the material. If material is not included in the article's Creative Commons licence and your intended use is not permitted by statutory regulation or exceeds the permitted use, you will need to obtain permission directly from the copyright holder. To view a copy of this licence, visit http://creativecommons.org/licenses/by/4.0/.

\section{References}

1. Bassler D, Antes G. Wie erhalte ich Antworten auf meine Fragen? In: Lehrbuch Evidenzbasierte Medizin in Klinik und Praxis. Deutscher Ärzte-Verlag, Köln. 2000.

2. Beck M, Rotter R, Gradl G, Herlyn P, Krober M, Mittlmeier T, Gierer P. Reliability and consequences of intraoperative 3D imaging to control positions of thoracic pedicle screws. Arch Orthop Trauma Surg Archiv fur orthopadische und UnfallChirurgie. 2012;132(10):1371-7. https://doi.org/10.1007/s0040 2-012-1555-y.

3. Berg EE. The sternal-rib complex. A possible fourth column in thoracic spine fractures. Spine. 1993;18(13):16-9.

4. Bransford R, Bellabarba C, Thompson JH, Henley MB, Mirza SK, Chapman JR. The safety of fluoroscopically-assisted thoracic pedicle screw instrumentation for spine trauma. J Trauma. 2006;60(5):1047-52. https://doi.org/10.1097/01.ta.0000215949 .95089 .18

5. Capen DA, Gordon ML, Zigler JE, Garland DE, Nelson RW, Nagelberg S. Nonoperative management of upper thoracic spine fractures. Orthop Rev. 1994;23(10):818-21.

6. Chan CY, Kwan MK, Saw LB. Safety of thoracic pedicle screw application using the funnel technique in Asians: a cadaveric evaluation. Eur Spine J. 2010;19(1):78-84. https://doi.org/10.1007/ s00586-009-1157-8.

7. Cho W, Le JT, Shimer AL, Werner BC, Glaser JA, Shen FH. The insertion technique of translaminar screws in the thoracic spine: computed tomography and cadaveric validation. Spine J. 2015;15(2):309-13. https://doi.org/10.1016/j.spinee.2014.09.013.

8. Dai L. Thoracic spine fractures. Chin Med Sci J Chung-kuo i hsueh k'o hsueh tsa chih. 2001;16(4):227-30.

9. Dhawan A, Klemme WR, Polly DW Jr. Thoracic pedicle screws: comparison of start points and trajectories. Spine. 2008;33(24):2675-81. https://doi.org/10.1097/BRS.0b013e3181 895 fea.

10. Dvorak M, MacDonald S, Gurr KR, Bailey SI, Haddad RG. An anatomic, radiographic, and biomechanical assessment 
of extrapedicular screw fixation in the thoracic spine. Spine. 1993;18(12):1689-94. https://doi.org/10.1097/00007632-19930 9000-00018.

11. Farrugia P, Petrisor BA, Farrokhyar F, Bhandari M. Practical tips for surgical research: research questions, hypotheses and objectives. Can J Surg J Canadien de Chirurgie. 2010;53(4):278-81.

12. Fischer S, Vogl TJ, Kresing M, Marzi I, Zangos S, Mack MG, Eichler K. Minimally invasive screw fixation of fractures in the thoracic spine: CT-controlled pre-surgical guidewire implantation in routine clinical practice. Clin Radiol. 2016;71(10):997-1004. https://doi.org/10.1016/j.crad.2016.06.112.

13. Fisher C, Singh S, Boyd M, Kingwell S, Kwon B, Li MJ, Dvorak $\mathrm{M}$. Clinical and radiographic outcomes of pedicle screw fixation for upper thoracic spine (T1-5) fractures: a retrospective cohort study of 27 cases. J Neurosurg Spine. 2009;10(3):207-13. https ://doi.org/10.3171/2008.12.SPINE0844.

14. Gattozzi DA, Friis LA, Arnold PM. Surgery for traumatic fractures of the upper thoracic spine (T1-T6). Surg Neurol Int. 2018;9:231. https://doi.org/10.4103/sni.sni_273_18.

15. Ghasemi AA, Ashoori S. Efficacy of pedicle screw fixation in unstable upper and middle thoracic spine fractures. Trauma Mon. 2016;21(1):e28627. https://doi.org/10.5812/traumamon.28627.

16. Gonzalvo A, Fitt G, Liew S, de la Harpe D, Vrodos N, McDonald M, Rogers MA, Wilde PH. Correlation between pedicle size and the rate of pedicle screw misplacement in the treatment of thoracic fractures: can we predict how difficult the task will be? $\mathrm{Br}$ J Neurosurg. 2015;29(4):508-12. https://doi.org/10.3109/02688 697.2015.1019414.

17. Harkonen M, Kataja M, Lepisto P, Paakkala T, Patiala H, Rokkanen P. Fractures of the thoracic spine. Clinical and radiological results in 98 patients. Arch Orthop Trauma Surg Archiv fur orthopadische und Unfall-Chirurgie. 1979;94(3):179-84.

18. Hongo M, Ilharreborde B, Gay RE, Zhao C, Zhao KD, Berglund LJ, Zobitz M, An KN. Biomechanical evaluation of a new fixation device for the thoracic spine. Eur Spine J. 2009;18(8):1213-9. https://doi.org/10.1007/s00586-009-0999-4.

19. Hu QF, Xu RM, Pan H, Zhou H, Lei W. Translaminar screw fixation in the upper thoracic spine: computed tomography-based quantitative laminar analysis and feasibility study of translaminar virtual screw placement. Cell Biochem Biophys. 2015;73(1):1918. https://doi.org/10.1007/s12013-015-0618-4.

20. Huckell CB, Powell J, Eggli S, Hu R. A comparative analysis of distraction rods versus Luque rods in thoracic spine fractures. Eur Spine J. 1994;3(5):270-5.

21. Husted DS, Yue JJ, Fairchild TA, Haims AH. An extrapedicular approach to the placement of screws in the thoracic spine: an anatomic and radiographic assessment. Spine. 2003;28(20):2324-30. https://doi.org/10.1097/01.BRS.0000085361.32600.63.

22. Kothe R, Matthias Strauss J, Deuretzbacher G, Hemmi T, Lorenzen M, Wiesner L. Computer navigation of parapedicular screw fixation in the thoracic spine: a cadaver study. Spine. 2001;26(21):E496-501.

23. Kwan MK, Chiu CK, Lee CK, Chan CY. Comparison between percutaneous fluoroscopic-guided and conventional open pedicle screw placement techniques for the thoracic spine: a safety evaluation in human cadavers. Bone Jt J. 2015;97-B(11):1555-61. https ://doi.org/10.1302/0301-620X.97B11.35789.

24. Lazaro BC, Deniz FE, Brasiliense LB, Reyes PM, Sawa AG, Theodore N, Sonntag VK, Crawford NR. Biomechanics of thoracic short versus long fixation after 3-column injury. J Neurosurg Spine. 2011;14(2):226-34. https://doi.org/10.3171/2010.10. SPINE09785.

25. Lehman RA Jr, Kang DG, Lenke LG, Gaume RE, Paik H. The ventral lamina and superior facet rule: a morphometric analysis for an ideal thoracic pedicle screw starting point. Spine J. 2014;14(1):137-44. https://doi.org/10.1016/j.spinee.2013.06.092.

26. Little AS, Brasiliense LB, Lazaro BC, Reyes PM, Dickman CA, Crawford NR. Biomechanical comparison of costotransverse process screw fixation and pedicle screw fixation of the upper thoracic spine. Neurosurgery. 2010; 66(3 Suppl Operative):178-182; discussion 182. https://doi.org/10.1227/01.neu.0000350869.35779 .05 .

27. Mac-Thiong JM, Labelle H, Rooze M, Feipel V, Aubin CE. Evaluation of a transpedicular drill guide for pedicle screw placement in the thoracic spine. Eur Spine. 2003;12(5):542-7. https://doi. org/10.1007/s00586-003-0549-4.

28. Marre B, Ballesteros V, Martinez C, Zamorano JJ, Ilabaca F, Munjin M, Yurac R, Urzua A, Lecaros M, Fleiderman J. Thoracic spine fractures: injury profile and outcomes of a surgically treated cohort. Eur Spine. 2011;20(9):1427-33. https://doi.org/10.1007/ s00586-011-1698-5.

29. Payer M. Unstable upper and middle thoracic fractures. Preliminary experience with a posterior transpedicular correction-fixation technique. J Clin Neurosci. 2005;12(5):529-33. https://doi. org/10.1016/j.jocn.2004.11.006.

30. Perry TG, Mageswaran P, Colbrunn RW, Bonner TF, Francis T, McLain RF. Biomechanical evaluation of a simulated T-9 burst fracture of the thoracic spine with an intact rib cage. J Neurosurg Spine. 2014; 21(3):481-88. https://doi.org/10.3171/2014.5.SPINE 13923

31. Reidy DP, Houlden D, Nolan PC, Kim M, Finkelstein JA. Evaluation of electromyographic monitoring during insertion of thoracic pedicle screws. J Bone Jt Surg Br. 2001;83(7):1009-14.

32. Reinhold M, Knop C, Beisse R, Audige L, Kandziora F, Pizanis A, Pranzl R, Gercek E, Schultheiss M, Weckbach A, Buhren $\mathrm{V}$, Blauth M. [Operative treatment of traumatic fractures of the thoracic and lumbar spinal column. Part I: epidemiology]. Der Unfallchirurg. 2009;112(1):33-42, 44-35. https://doi.org/10.1007/ s00113-008-1524-7

33. Roussouly P, Pinheiro-Franco JL. Sagittal parameters of the spine: biomechanical approach. Eur Spine J. 2011;20(Suppl 5):578-85. https://doi.org/10.1007/s00586-011-1924-1.

34. Roy-Camille R, Saillant G, Berteaux D, Salgado V. Osteosynthesis of thoraco-lumbar spine fractures with metal plates screwed through the vertebral pedicles. Reconstr Surg Traumatol. 1976;15:2-16.

35. Schnake KJ, Konig B, Berth U, Schroeder RJ, Kandziora F, Stockle U, Raschke M, Haas NP. Accuracy of CT-based navitation of pedicle screws in the thoracic spine compared with conventional technique. Der Unfallchirurg. 2004;107(2):104-12. https:// doi.org/10.1007/s00113-003-0720-8.

36. Schouten R, Keynan O, Lee RS, Street JT, Boyd MC, Paquette SJ, Kwon BK, Dvorak MF, Fisher CG. Health-related quality-of-life outcomes after thoracic (T1-T10) fractures. Spine J. 2014;14(8):1635-42. https://doi.org/10.1016/j.spine e.2013.09.049.

37. Singh H, Rahimi SY, Yeh DJ, Floyd D. History of posterior thoracic instrumentation. Neurosurg Focus. 2004;16(1):E11. https:// doi.org/10.3171/foc.2004.16.1.12.

38. Spiegl UJA, Schnake KJ, Hartmann F, Katscher S, Riehle M, Scheyerer MJ, Schmeiser G, Siekmann H, Osterhoff G. Traumatic fractures of the thoracic spine. Z Orthop Unfallchirurgie. 2020. https://doi.org/10.1055/a-1144-3846.

39. Vaccaro AR, Rizzolo SJ, Allardyce TJ, Ramsey M, Salvo J, Balderston RA, Cotler JM. Placement of pedicle screws in the thoracic spine. Part I: morphometric analysis of the thoracic vertebrae. J Bone Jt Surg Am. 1995;77(8):1193-9. https://doi. org/10.2106/00004623-199508000-00008. 
40. Vaccaro AR, Rizzolo SJ, Balderston RA, Allardyce TJ, Garfin SR, Dolinskas C, An HS. Placement of pedicle screws in the thoracic spine. Part II: an anatomical and radiographic assessment. J Bone Jt Surg Am. 1995;77(8):1200-6. https://doi.org/10.2106/00004 623-199508000-00009.

41. Vassal M, Lonjon G, Knafo S, Thouvenin Y, Segnarbieux F, Lonjon N. Surgical treatment of thoracic spine fractures. Outcomes on 50 patients at 23 months follow-up. Orthop Traumatol Surg Res OTSR. 2014;100(5):475-80. https://doi.org/10.1016/j. otsr.2014.05.007.

42. Wang X, Liu Y, Wang X, Chen H, Cao P, Tian Y, Wu X, Chen Y, Yuan W. Beneficial effects of percutaneous minimally invasive surgery for patients with fractures in the thoracic spine. Exp Ther Med. 2018;16(6):5394-9. https://doi.org/10.3892/etm.2018.6887.

43. Rt W, Watkins R 3rd, Williams L, Ahlbrand S, Garcia R, Karamanian A, Sharp L, Vo C, Hedman T. Stability provided by the sternum and rib cage in the thoracic spine. Spine. 2005;30(11):1283-6.
44. White AA, Panjabi MM. Clinical biomechanics of the spine, vol. 2. Philadelphia: JB Lippincott Company; 1990.

45. Wu H, Gao ZL, Wang JC, Li YP, Xia P, Jiang R. Pedicle screw placement in the thoracic spine: a randomized comparison study of computer-assisted navigation and conventional techniques. Chin J Traumatol Zhonghua Chuang Shang za zhi. 2010;13(4):201-5.

46. Yue JJ, Sossan A, Selgrath C, Deutsch LS, Wilkens K, Testaiuti M, Gabriel JP. The treatment of unstable thoracic spine fractures with transpedicular screw instrumentation: a 3-year consecutive series. Spine. 2002;27(24):2782-7. https://doi.org/10.1097/01. BRS.0000035727.46428.BE.

47. Zhang H, Zhao Q, He B, Liu J, Hao D, Guo H. Optimal timing for type $\mathrm{C} 3$ thoracic fractures with posterior surgical approach: a retrospective cohort study. J Orthop Sci. 2015;20(4):689-94. https ://doi.org/10.1007/s00776-015-0723-7.

48. Zifko B, Schodl F, Holzmuller H. Conservative treatment of fractures of the thoracic spine. Hefte zur Unfallheilkunde. 1971;108:84-7. 